\title{
Role of TSH and O-GTT screening in pregnancy induced hypertension
}

\author{
Aruna Verma*, Monika Kashyap, Abhilasha Gupta
}

Department of Obstetrics \& Gynaecology, Lala Lajpat Rai Memorial Medical College, Meerut, Uttar Pradesh, India

Received: 5 August 2014

Accepted: 19 August 2014

\section{*Correspondence:}

Dr. Aruna Verma,

E-mail: arunatonk@yahoo.co.in

(C) 2014 Verma A et al. This is an open-access article distributed under the terms of the Creative Commons Attribution Non-Commercial License, which permits unrestricted non-commercial use, distribution, and reproduction in any medium, provided the original work is properly cited.

\begin{abstract}
Background: Objective of current study was to evaluate the prevalence of hypothyroidism and gestational diabetes in PIH patients and its impact on maternal and foetal outcome.

Methods: A case-control study of 200 antenatal women; group A - PIH, 100 and group B normotensive - 100 women was carried out. Serum TSH and O-GTT screening was done in both groups.

Results: In group A, 59\% women had mild preeclampsia, 41\% women had severe preeclampsia. Significantly raised $\mathrm{TSH}$ titre $(>3 \mathrm{mIU} / \mathrm{ml})$ was found in $36 \%$ women in group A and $9 \%$ women in group B (P value $<0.0001)$. GDM was found in $33 \%$ women in group A and $8 \%$ women in group B (P value 0.0033).

Conclusions: Incidence of both hypothyroidism (subclinical and clinical) and gestational diabetes is significantly high in women with PIH.
\end{abstract}

Keywords: Pregnancy induced hypertension, Hypothyroidism, Gestational diabetes, Pregnancy

\section{INTRODUCTION}

Preeclampsia and eclampsia are still an important cause of maternal and peri-natal morbidity and mortality in the developing countries. Although pregnancy is usually associated with very mild hyper-thyroxinaemia, preeclamptic women have high incidence of hypothyroidism that might correlate with the severity of preeclampsia. On the other hand, preeclampsia has also been observed in $16.7 \%$ of sub-clinical cases and $43.7 \%$ of overt cases of hypothyroidism during pregnancy. The mechanism of hypothyroidism in pre-eclamptic women has not been identified but the changes in thyroid function during pregnancy are accounted for by high circulating oestrogens.

The incidence of type 1 and type 2 diabetes in pregnancy is $0.3 \%$ whereas that of gestational diabetes is between 3 $12 \%$. Majority of women with carbohydrate intolerance during pregnancy do not have signs and or symptoms. However, there is a significant increase in maternal and foetal morbidity like preeclampsia, chronic hypertension, retinopathy, nephropathy, diabetic ketoacidosis, chronic artery disease and infections in mother. Abortions, congenital malformations, growth restrictions, foetal macrosomia, unexplained foetal demise and perinatal morbidity, preterm delivery, birth injuries, neonatal hypoglycaemia, neonatal hypocalcaemia, respiratory distress, metabolic syndrome, postnatal hyperbilirubinaemia, polycythaemia in foetus. The obstetricians are increasingly becoming aware of the potential or adverse effects of pre-eclampsia and hypothyroidism on the outcome of pregnancy and have a high index of suspicion.

Thus the present study was done to evaluate the O-GTT status and thyroid status in pregnant women with pregnancy induced hypertension in the second half of pregnancy.

\section{METHODS}

The study was a case-control study of 200 pregnant women conducted in department of obstetrics and gynaecology Lala Lajpat Rai memorial medical college, 
Meerut in year 2011-2012. Total 200 patients were divided into two groups of 100 patients each. Group A had 100 patients with pregnancy induced hypertension. Group B had 100 patients with blood pressure within normal limits.

Pregnant patients of Age group between 18 to 40 years were selected and in group B measurement of 2 elevated blood pressure reading more than $140 / 90 \mathrm{mmHg}$, at least 6 hours apart, with or without proteinuria (reading of +1 or more on dip stick).

All women with history of critical illness during pregnancy, any medication that might affect thyroid function, history of renal disease, hypertension before pregnancy, multiple pregnancy, molar gestation, severe hypo-albuminaemia were excluded from the study.

Patients of both the groups were included in the study in their second half of pregnancy. Serum TSH level and OGTT was done in both the groups before delivery and before the initiation of any antihypertensive in group A.

All samples were sent to the laboratory with different code numbers, deciphered at the time of the analysis of data. Sera were separated and stored at $20^{\circ} \mathrm{C}$ until assayed. Thyroid stimulating hormone was measured using chemiluminescence immunoassay (CLIA) using microplate luminometer.

The following reference ranges of TSH were taken (as recommended by American Thyroid association 2011)

Second trimester - 0.2-3.0 mIU/L
Third trimester - 0.3-3.0 mIU/L

In all women, oral glucose tolerance test (O-GTT) was also done with 75 grams anhydrous glucose and plasma glucose was measured fasting, one and two hour in the morning after an overnight fast of at least 8 hours. The diagnosis of GDM is made when any of the following plasma glucose values are exceeded (as per IADPSG and ADA):

Fasting $>92 \mathrm{mg} / \mathrm{dL}(5.1 \mathrm{mmol} / \mathrm{L})$

$1 \mathrm{~h}>180 \mathrm{mg} / \mathrm{dL}(10.0 \mathrm{mmol} / \mathrm{L})$

$2 \mathrm{~h}>153 \mathrm{mg} / \mathrm{dL}(8.5 \mathrm{mmol} / \mathrm{L})$

All women will be followed up through their antenatal, intrapartum and postpartum period.

\section{RESULTS}

In group A out of 100 pregnant women, 59\% had mild pre-eclampsia, $41 \%$ women had severe pre-eclampsia.

Significantly raised $\mathrm{TSH}$ titre $(>3 \mathrm{mIU} / \mathrm{ml})$ was found in $36 \%$ women in PIH group A $(40.0 \%$ had mild preeclampsia and $75.9 \%$ had severe pre-eclampsia) whereas only $9 \%$ women in normotensive group B had raised $\mathrm{TSH}$ titre $(>3 \mathrm{mIU} / \mathrm{ml})(\mathrm{P}$ value $<0.0001)$ which is statistically significant.

GDM was found in 33\% women in PIH group A $35.6 \%$ women had mild preeclampsia and $29.3 \%$ women had severe preeclampsia) whereas only $8 \%$ women in normotensive group $\mathrm{B}$ were gestational diabetic ( $\mathrm{P}$ value 0.003 ) with statistically significant difference.

Table 1: Incidence of hypothyroidism in group A and group B.

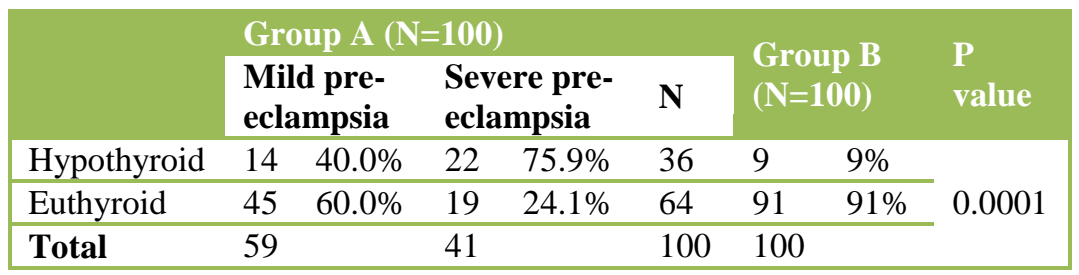

Table 2: Incidence of gestational diabetes in group A and group B.

\begin{tabular}{|c|c|c|c|c|c|c|c|c|}
\hline \multirow[b]{3}{*}{ Gestational diabetic } & \multicolumn{5}{|c|}{ Group A $(\mathrm{N}=100)$} & \multirow{2}{*}{\multicolumn{2}{|c|}{$\begin{array}{l}\text { Group B } \\
(\mathbf{N}=\mathbf{1 0 0})\end{array}$}} & \multirow[b]{2}{*}{$\begin{array}{l}\text { P } \\
\text { value }\end{array}$} \\
\hline & \multicolumn{2}{|c|}{$\begin{array}{l}\text { Mild pre- } \\
\text { eclampsia }\end{array}$} & \multicolumn{2}{|c|}{$\begin{array}{l}\text { Severe pre- } \\
\text { eclampsia }\end{array}$} & \multirow{2}{*}{$\begin{array}{l}\mathbf{N} \\
33\end{array}$} & & & \\
\hline & 21 & $35.6 \%$ & 12 & $29.3 \%$ & & 8 & $8 \%$ & \\
\hline Non diabetic & 38 & $64.4 \%$ & 29 & $70.7 \%$ & 67 & 92 & $92 \%$ & 0003 \\
\hline Total & 59 & & 41 & & 100 & 100 & & \\
\hline
\end{tabular}




\section{DISCUSSION}

Various factors are responsible for normal development of foetus and uncomplicated birth. This study was planned to compare the prevalence of hypothyroidism and gestational diabetes in $\mathrm{PIH}$ patients and in normotensive patients.

On statistical analysis and calculations of various observations between PIH patients and normotensive patients, in this study we concluded that hypothyroidism is significantly more incidence in PIH patients as compared to normotensive patients.

In a study conducted by Ashok kumar et al. ${ }^{1}$ (2005) concluded that out of 82 pregnant women in each group, $33(42.2 \%)$ women in pre-eclamptic study group and $10(12.2 \%)$ in control group had abnormal TSH titre $(>5 \mathrm{miu} / \mathrm{ml})$. This difference between the two groups is found to be statistically significant $(\mathrm{P}<0.001)$.

Khaliq $\mathrm{F}$ et al. ${ }^{2}$ (1999) found that serum total triiodothyronine $\left(\mathrm{TT}_{3}\right)$ and total thyroxine $\left(\mathrm{TT}_{4}\right)$ were decreased significantly $(\mathrm{P}<0.001)$ and $\mathrm{TSH}$ was increased significantly $(\mathrm{P}<0.001)$ in pre-eclampsia as compared to normal pregnancy.

Whereas Nahid Mostaghel et al. ${ }^{3}$ (2008) found that mean TSH levels were not significantly higher in pre-eclamptic group as compared to controls $(\mathrm{P}>0.05)$. This difference between the two groups is not found to be statistically significant $(\mathrm{P}>0.05)$. They concluded that the association between thyroid function and preeclampsia need further investigation because of the small number of patients in the study.

Qublan HS et al. ${ }^{4}$ (2003) concluded that the thyroid function is not altered in severe pre-clampsia, therefore it does not reflect the severity of pre-eclampsia

Cleary-Goldman et al. 2008 found that maternal thyroid hypo function is not associated with a consistent pattern of adverse outcomes.

Our study reveals a strong relationship between pregnancy induced hypertension and hypothyroidism. As we know pregnancy induced hypertension is one of the important causes of morbidity and mortality in mother and the neonate, this relationship needs to be further evaluated so that we can prevent such serious disease just by prior screening of serum TSH.

In our study we also found more incidence of gestational diabetes in PIH patients as compared to normotensive patients.

Chris L. Bryson et al. ${ }^{6}$ (2003) concluded that gestational diabetes was more common in PIH group $(3.9 \%$ in eclamptics, $4.5 \%$ in severe pre-eclamptics, and $4.4 \%$ in both mild pre-eclamptics and those with gestational hypertension) than in controls $(2.7 \%)$.
Maria I. Schmidt et al. ${ }^{7}$ 1991-1995 concluded that women diagnosed with GDM based on a 2-h 75-g OGTT, independently of various risk factors such as maternal age and obesity, have an increased developing preeclampsia, and suffering a perinatal death.

Lauri Suhonen et al. ${ }^{8}$ may 1993 concluded that frequency of both chronic hypertension $(2.5 \%$ vs. $0.3 \%, \mathrm{P}<0.05)$ and pregnancy induced hypertension and preeclampsia ( $19.8 \%$ vs. $6.1 \%, \mathrm{P}>0.001)$ were higher in the gestational diabetic group, but not in the borderline group when compared with the controls.

Table 3: Comparison of previous studies on hypothyroidism and PIH.

\begin{tabular}{|lll|}
\hline Study & $\begin{array}{l}\text { \% of hypothyroid } \\
\text { patients in PIH } \\
\text { group }\end{array}$ & $\begin{array}{c}\% \text { of patients in } \\
\text { normotensive } \\
\text { group }\end{array}$ \\
\hline $\begin{array}{l}\text { Ashok Kumar et } \\
\text { al. 2005 }\end{array}$ & $42.2 \%$ & $12.2 \%$ \\
\hline $\begin{array}{l}\text { Khaliq F et al. } \\
1999\end{array}$ & $\begin{array}{l}\text { Significant difference between both } \\
\text { groups }\end{array}$ \\
\hline $\begin{array}{l}\text { Nahid Mostaghel } \\
\text { et al. 2008 }\end{array}$ & $6.06 \%$ \\
\hline $\begin{array}{l}\text { Cleary-Goldman } \\
\text { et al 2008 }\end{array}$ & $\begin{array}{l}\text { No significant difference between both } \\
\text { groups }\end{array}$ \\
\hline $\begin{array}{l}\text { Qublan HS et al. } \\
\text { 2003 }\end{array}$ & $\begin{array}{l}\text { No significant difference between both } \\
\text { groups }\end{array}$ \\
\hline Our study & $36 \%$ & $9.39 \%$ \\
\hline
\end{tabular}

Table 4: Comparison of previous studies on gestational diabetes and PIH.

\begin{tabular}{|ll|} 
Study & $\begin{array}{l}\text { Comparison of prevalence of } \\
\text { diabetics between PIH group } \\
\text { and normotensive patients }\end{array}$ \\
$\begin{array}{l}\text { Chris L. Bryson et al. } \\
(2003)\end{array}$ & $\begin{array}{l}\text { Significantly higher prevalence of } \\
\text { diabetics among PIH group }\end{array}$ \\
\hline $\begin{array}{l}\text { Maria I. Schmidt et al. } \\
(1991-1995)\end{array}$ & $\begin{array}{l}\text { Significantly higher prevalence of } \\
\text { PIH in diabetics }\end{array}$ \\
\hline $\begin{array}{l}\text { Lauri Suhonen et al. } \\
(1993)\end{array}$ & $\begin{array}{l}\text { Significantly higher prevalence of } \\
\text { PIH in diabetics }\end{array}$ \\
\hline & $\begin{array}{l}\text { Significantly higher prevalence of } \\
\text { PIH in diabetics and significantly } \\
\text { higher prevalence of diabetics } \\
\text { among PIH group. }\end{array}$ \\
\hline
\end{tabular}

\section{CONCLUSION}

It is concluded that thyroid abnormalities (especially hypothyroidism) are strongly related with pregnancy induced hypertension and gestational diabetes. As we know that both PIH and GDM are important causes of morbidity and mortality in mother and neonates like intra-uterine growth restriction, abruptio placentae, postpartum haemorrhage, intrauterine death of foetus, preterm deliveries, low birth weight, NICU admissions. 
Thus these relationships need further evaluation so that we can prevent such serious disease just by prior screening of serum TSH and O-GTT.

\section{ACKNOWLEDGMENTS}

We acknowledge the contribution of all the patients and doctors of department of obstetrics and gynaecology, LLRM medical college involved in this study.

\section{Funding: No funding sources}

Conflict of interest: None declared

Ethical approval: The study was approved by the institutional ethics committee

\section{REFERENCES}

1. Kumar A, Ghosh BK, Murthy NS. Maternal thyroid hormonal status in pre-eclampsia. Indian J Med Sci. $2005 \mathrm{Feb} ; 59(2): 57-63$

2. Khaliq F, Singhal U, Arshad Z, Hossain MM. Thyroid functions in preeclampsia and its correlation with maternal age, parity, severity of blood pressure and serum albumin. Indian J Physiol Pharmacol. 1999;43(2):193-8.

3. Nahid Mostaghel, Tavanayanfar Elham, Neisani Samani Elham. Association of maternal hypothyroidism with preeclampsia. Iranian J Pathol. 2008;3(2):51-4.

4. Qublan HS, Al-Kaisi IJ, Hindawi IM, Hiasat MS, Awamleh I, Hamaideh AH, et al. Severe preeclampsia and maternal thyroid function. J Obstet Gynaecol. 2003 May;23(3):244-6.

5. Cleary-Goldman J, Malone FD, Lambert-Messerlian G, Sullivan L, Canick J, Porter TF, et al. Maternal thyroid hypofunction and pregnancy outcome. Obstet Gynaecol. 2008 Jul;112(1):85-92.

6. Bryson CL, Ioannou GN, Rulyak SJ, Critchlow C. Association between gestational diabetes and pregnancy induced hypertension. Am J Epidemiol. 2003 Dec;158(12):1148-53.

7. Schmidt MI, Duncan BB, Reichelt AJ, Branchtein L, Matos MC, Costa e Forti A, et al. Gestational diabetes mellitus diagnosed with a 2-h $75-\mathrm{g}$ oral glucose tolerance test and adverse pregnancy outcome. Diabet Care. 2001 Jul;24(7):1151-5.

8. Suhonen L, Teramo K. Hypertension and preeclampsia in women with gestational glucose intolerance. Acta Obstet Gynecol Scand. 1993 May;72(4):269-72.

DOI: $10.5455 / 2320-1770$. ijrogog20140974

Cite this article as: Verma A, Kashyap M, Gupta A. Role of TSH and O-GTT screening in pregnancy induced hypertension. Int J Reprod Contracept Obstet Gynecol 2014;3:720-3. 